\title{
Biodiversity and Carbon Stock in the SODECAO Agroforestry System of Center Region of Cameroon: Case of Talba Locality
}

\author{
Madountsap Tagnang Nadège*, Zapfack Louis, Chimi Djomo Cédric, \\ Kabelong Banoho Louis-Paul, Tsopmejio Temfack Ingrid, Forbi Preasious Funwi, \\ Ntonmen Yonkeu Amandine Flore, Nasang Julliete Mancho
}

Department of Plant Biology, Faculty of Science, University of Yaounde, Yaounde, Cameroon

Email address:

madnadege@yahoo.fr (M. T. Nadège), chimicedric10@yahoo.fr (C. D. Cédric)

${ }^{*}$ Corresponding author

\section{To cite this article:}

Madountsap Tagnang Nadège, Zapfack Louis, Chimi Djomo Cédric, Kabelong Banoho Louis-Paul, Tsopmejio Temfack Ingrid, Forbi Preasious Funwi, Ntonmen Yonkeu Amandine Flore, Nasang Julliete Mancho. Biodiversity and Carbon Stock in the SODECAO Agroforestry System of Center Region of Cameroon: Case of Talba Locality. American Journal of Agriculture and Forestry. Vol. 5, No. 4, 2017, pp. 121-129. doi: 10.11648/j.ajaf.20170504.16

Received: May 18, 2017; Accepted: June 3, 2017; Published: July 13, 2017

\begin{abstract}
This study was carried out in typical SODECAO (Cocoa Development Company) agroforestry systems of Talba locality (Central region of Cameroon). The objective was to assess the role of typical SODECAO agroforestry systems in the conservation of biodiversity and the climate change mitigation. Trees inventories of diameter $\geq 10 \mathrm{~cm}$ and all cocoa trees were carried out in 40 plots of $25 \mathrm{~m}$ x $25 \mathrm{~m}$. Cocoa Agroforests (CAF) sampled were stratified in three age classes ( $\geq 10,10-20$ and 20 years represented by young, middle and old cocoa agroforests respectively). Their aboveground biomass was estimated using allometric equations. A total of 21 trees species belonging to 19 genera and 14 families were inventoried. Of the total number of species of trees recorded, 24\% were threatened looking at their IUCN (International Union for Conservation of Nature) status. Indeed, 9 species (43\%) were indigenous and 12 (57\%) exotic. The biodiversity indices values found were: Shannon (2.7), Pielou (0.7) and Simpson (0.9). The estimation of the specific wealth varied from $73-81 \%$ in CAF. The abundance of cocoa shrubs and associated tree species were estimated to 1104 stems ha $^{-1}$ and 77 stems ha $^{-1}$ respectively. The total carbon stock was $100 \mathrm{Mg} \mathrm{Cha}^{-1}$. Cocoa shrubs and associated tree species carbon stock were 30 and $70 \mathrm{Mg} \mathrm{Cha}^{-1}$ respectively. According to the three age classes considered, there were a significantly differences between their carbon stocks (ANOVA, $\mathrm{p}<0.05$ ). SODECAO cocoa agroforestry systems could be recognized amongst one of the major issues of international negotiations for the fight against climate change.
\end{abstract}

Keywords: SODECAO, Biodiversity, IUCN Status, Carbon Stock, Talba

\section{Introduction}

Cameroon's forest-savannah transition zone extends over nearly $10000 \mathrm{~km}^{2}$ and contains a particular and important biodiversity [1]. With the intensification of agricultural and pastoral activities, the superficies of this area decline steadily over time $[2,3]$. However, Cocoa Agroforest (CAF) systems which are the main agricultural system developed in this area represents the main form of conversion of natural ecosystems [4].
Global world agroforestry systems cover 6.4 million $\mathrm{km}^{2}$ (6400 ha), about $13 \%$ of the total agricultural area worldwide [5]. According to Deheuvels [5], these superficies will probably increase in a few years. For Nair [6], the area of these systems is estimated at $\approx 1$ billion hectares which is the equivalence of one third of Africa's area. However, these two authors, although with different figures, showed the importance of cocoa agroforests in the conservation of biodiversity.

In Cameroon, cocoa plantation is a major source of income for more than 400,000 families [7-9]. These systems are an 
alternative to conventional agriculture [10], economic, sociocultural capital, a source of more and diversified benefits and incomes [11-15]. Moreover, more studies have shown that, CAF are recognized for their ability to store important quantities of carbon, thus providing remarkable potential to fight against climate change [16-19]. However, the fluctuation in the price of cocoa in the world markets and the increase in the purchase prices of this raw material amongst rural households encourages them to extend their cocoa farms at the detriment of natural ecosystems [3-20].

Faced with the economic and ecological stakes, some NonGovernmental Organizations (NGOs) are working in some frameworks to encourage cocoa farmers to apply the Cocoa Development Corporation (SODECAO) cocoa production recommendations since years of 1980. These recommendations favor a semi-improved agroforestry system where cocoa trees are cultivated under the managed forest [21-22]. Moreover, the respect of the technical recommendations of SODECAO by farmers, in addition to increasing their incomes, maintains an important biodiversity amongst species with a status of vulnerability or the native species [23-24]. It is also a cultivation model in which the plant material used is improved, shade adjustment is recommended and the alternation between cocoa and other trees species is $3 \mathrm{~m} \times 3 \mathrm{~m}$ [25-28]. The alignment of these trees species in this system makes it possible to have a homogeneous density at the surface unit, so that each tree has the same volume of useful floor and is subjected to the same luminosity, which ensures harmonious development [29]. In the locality of Talba, supported by SODECAO's management services, the typical SODECAO agroforestry system is one of the systems more practiced in this area. In order to examine the relevance of this type of farming system in mitigating the effects of climate change, this study aims to contribute of the trees biodiversity knowledge of typical SODECAO agroforestry systems of Talba locality and their capacity to reduce the effect of climate change.

\section{Material and Methods}

\subsection{Study Area}

This study was carried out in Talba village, located in Mbangassina sub-division of Mbam-and-Kim Division of the Central region of Cameroon. Talba is located at latitude $4^{\circ} 34$ ' 42 "N and longitude $11^{\circ} 28^{\prime} 33^{\prime}$ E. Its population is estimated at 2284 inhabitants. It is an area where there is the intensification of agriculture practices especially cocoa plantation [3]. The soils of Talba are either ferralitic, clayeysandy or lateritic in function of the place. These soils are rich in organic matter and are suitable for diversified agriculture [30]. The locality presents diverse sorts of vegetation constituted by secondary equatorial forest, shrub, savanna and even steppe. In general, it is a transition zone between forest and savannah. Climate are typically Guinean equatorial with four unequal seasons that alternate during the year with two dry and two wet seasons. The main rainy season runs from mid-August to mid-November, while the small rainy season runs from April to June; the main dry season is between mid-November and March while the small dry season is between June And July [3]. The average annual temperature fluctuates between 22 and $32^{\circ} \mathrm{C}$ with the thermal amplitude spanning $8-13^{\circ} \mathrm{C}$. Rainfall is between 1300 and $1500 \mathrm{~mm}$ per year [32].

\subsection{Data Collection}

Sampling was done in CAF of different age classes. A total of 40 plots $(2.5 \mathrm{ha})$ of $25 \mathrm{~m} \times 25 \mathrm{~m}$ were sampled [11] The three age classes considered were: CAF of $\geq 10$ years, represented by 15 plots sampling, CAF with ages spanning $10-20$ years (15 plots) and the old CAF with age $>20$ years (15 plots). In each of these plots, trees inventory with a diameter $\geq 10 \mathrm{~cm}$ and all cocoa trees present were recorded. The diameter of all trees species associated was measured at $1.30 \mathrm{~m}$ aboveground and $0.3 \mathrm{~m}$ above the buttresses for the trees having buttresses of more than $1.30 \mathrm{~m}$. The diameter of the cocoa trees was measured at $0.30 \mathrm{~m}$ aboveground [19]. A herbarium made up of the botanical samples of the species inventoried in the field was used to confirm their identification by comparing with the samples available at the National Herbarium of Yaoundé.

\subsection{Data Analysis}

\subsubsection{Biodiversity Indices}

Shannon diversity index was calculated with the following formula: $\mathrm{ISH}=-\Sigma \mathrm{Ni} / \mathrm{N} \log 2 \mathrm{Ni} / \mathrm{N}$ where $\mathrm{Ni}=$ number of species $\mathrm{i} ; \mathrm{N}=$ number of species (1). This index is the most recommended in the standard comparative study because it is independent of the size of the population studied and gives more importance to rare species [33].

The equitability of Pielou EQ: EQ $=$ ISH $/ \log 2 \mathrm{~N}$; is between 0 and 1 . A low equitability represents a great importance of some dominant species (2).

The Simpson index reports on the abundance of one or few species, expresses the probability that two random individuals in an infinite population belongs to the same species. It is calculated using the formula $\mathrm{D}^{\prime}=\Sigma(\mathrm{ni} / \mathrm{N}) 2$ with ni: number of individuals for $\mathrm{i}$ species and $\mathrm{N}$ the total number of individuals (3).

The Chao estimator [34] is based on the concept that the number of unobserved species is estimated from those observed one or two times and in this case the singletons and doubletons used represent a priori to reduce the bias, a biased estimator, where the bias estimated is the number of species observed as a significant part of the information from Jackknife technics [35] has been developed as a method.

The threat levels of trees species inventoried in this study area were assessed on the literature information in the International Union for Conservation of Nature (IUCN) Red list of Categorization and Criteria for Cameroon plants species [36].

\subsubsection{Basal Area}

Basal area was calculated for cocoa trees and trees associate recorded. For each tree, basal area is expressed by 
the following formula $\mathrm{S}=\pi\left(\mathrm{Di}^{2} / 4\right)$ where $\mathrm{Di}$ is the diameter (m) of the tree $\mathrm{i}, \pi=3.14$ (4). In each plots $\left(625 \mathrm{~m}^{2}\right)$, basal area corresponds to the sum of the basal areas of all trees and cocoa shrubs: $\mathrm{S}=\Sigma \pi\left(\mathrm{Di}^{2} / 4\right)$ (5). It was therefore extrapolated to the hectare using the Expansion Factor: EF = $10000 / 625 \mathrm{~m}^{2}$ for each plot (7).

\subsubsection{Aboveground Biomass Estimation}

Carbon stocks were estimated with the non-destructive method using allometric equations. As such the measured variables of trees (diameter, wood density and height for palm trees) collected on each tree and cocoa shrubs were used for the estimation of their aboveground biomass. The density data used were those available in "Global Wood Density" [37].

The allometric equation developed by Chave [38] takes into account the tree's diameter, the wood density and the environmental index "E", which includes seasonal temperature, drought intensity and the seasonality of precipitation are recommended but in the context of this study data about environmental index could not be recorded. It is for this reason that the allometric equation developed by Chave [39] was used for aboveground biomass estimation of cocoa shrubs and associated trees. This equation takes into account the tree diameter and the wood density of the species. It is the equation most commonly used in carbon estimation studies in Cameroon's forests [17, 24, 40, 41] but also the most recommended in the tropical zone [42]. Chave's equation is defined by:

$$
\mathrm{Y}=\rho \times \mathrm{e}^{\left(-1,499+2,148 \times \ln (\mathrm{D})+0,207 \times(\ln (\mathrm{D}))^{2}-0,028 \times(\ln (\mathrm{D}))^{3}\right)}
$$

Where $\mathrm{Y}$ is aboveground biomass $(\mathrm{kg}), \mathrm{D}$ is the diameter $(\mathrm{cm})$ at breast height $(1.30 \mathrm{~m}) ; \rho$ is the specific wood density (8). Since Chave's equation cannot be applied to species such as Elaeis guineensis, the allometric equation developed by
Cummings [43] was used:

$\mathrm{Y}=4.5+7.7 \times \mathrm{H} . \mathrm{Y}=$ aboveground biomass $(\mathrm{kg}) ; \mathrm{H}=$ total height $(\mathrm{m})(9)$.

The aboveground biomass values obtained in each $625 \mathrm{~m}^{2}$ were extrapolated per hectare for all the plots sampled using the same formula as above [44], The aboveground biomass estimated from this equation was then multiplied by 0.47 for the carbon stock estimation [17].

The statistical analyses were carried out using software $\mathrm{R}$ (3.1.3). The analysis of variance (ANOVA) and Turkey's test were used to compare the different classes of CAF (young, middle and old). These tests were preceded by the normality test of Shapiro-Wilk which showed that these data do not follow a normal distribution $(\mathrm{p}<0.05)$. The Principal Component Analysis (PCA) was carried out using the "ade4TkGUI" package and concerned the first 2 dimensions which gave the highest percentages of information.

\section{Results}

\subsection{Plant Diversity of SODECAO's Cocoa Agroforests}

The inventory carried out on the young, middle and old cocoa agroforests yielded a total of 2891 woody species 2700 cocoa trees and 191 associated trees. Twenty one tree species associated to cocoa trees belonging to 19 genera and 14 families were recorded. The most represented families were; Malvaceae (with 4 species), Rutaceae, Guttiferae, Moraceae, Bombacaceae (with 2 species each). Species like Terminalia superba (13.1\%, most abundant of all inventoried trees species), Ricinodendron heudelotii (11\%) and Dacryodes edulis $(10.5 \%)$ are dominant in the SODECAO CAF system of Talba locality. The other species were represented by less than $10 \%$ each (Table 1).

Table 1. Proportion and IUCN status of trees species recorded in SODECAO cocoa agroforests system type.

\begin{tabular}{|c|c|c|c|c|c|c|c|c|}
\hline Species & Families & Abundance & Proportion (\%) & $\begin{array}{l}\text { Status } \\
\text { UICN }\end{array}$ & YC & MC & OC & Groups \\
\hline Terminalia superba Engl. \& Diels & Combretaceae & 25 & 13,1 & LC & $\mathrm{X}$ & $\mathrm{X}$ & $\mathrm{X}$ & Ex \\
\hline Ricinodendron heudelotii (Baill.) Pierre ex Baill. & Euphorbiaceae & 21 & 11 & $\mathrm{NE}$ & $\mathrm{X}$ & $\mathrm{X}$ & $X$ & Ex \\
\hline Dacryodes edulis (G.Don) H.J. Lam & Burseraceae & 20 & 10,5 & $\mathrm{LC}$ & $\mathrm{X}$ & $\mathrm{X}$ & $\mathrm{X}$ & Ex \\
\hline Citrus reticulata Blanco & Rutaceae & 19 & 9,9 & $\mathrm{LC}$ & & $\mathrm{X}$ & $\mathrm{X}$ & Ex \\
\hline Cola acuminata (P. Beauv.) Schott \& Endl. & Malvaceae & 18 & 9,4 & $\mathrm{LC}$ & $\mathrm{X}$ & $\mathrm{X}$ & $X$ & In \\
\hline Persea americana Mill & Lauraceae & 17 & 8,9 & $\mathrm{LC}$ & $\mathrm{X}$ & $\mathrm{X}$ & $X$ & Ex \\
\hline Ceiba pentandra (Linne) Gaertner & Bombacaceae & 10 & 5,2 & $\mathrm{LC}$ & $\mathrm{X}$ & $\mathrm{X}$ & $\mathrm{X}$ & In \\
\hline Garcinia kola Heckel & Guttiferae & 10 & 5,2 & VU & & $\mathrm{X}$ & $\mathrm{X}$ & In \\
\hline Myrianthus arboreus $\mathrm{P}$. Beauv. & Moraceae & 1 & 0.5 & $\mathrm{LC}$ & $\mathrm{X}$ & & & In \\
\hline Citrus sinensis (L.) Osbeck & Rutaceae & 9 & 4,7 & $\mathrm{LC}$ & $\mathrm{X}$ & $\mathrm{X}$ & $\mathrm{X}$ & Ex \\
\hline Cola pachycarpa K. Schum. & Malvaceae & 8 & 4,2 & $\mathrm{LC}$ & $\mathrm{X}$ & & $X$ & Ex \\
\hline Triplochyton scleroxylon K. Schum. & Malvaceae & 8 & 4,2 & VU & $\mathrm{X}$ & $\mathrm{X}$ & $X$ & In \\
\hline Elaeis guineensis Jacq. & Palmae & 7 & 3,7 & $\mathrm{NE}$ & $\mathrm{X}$ & $\mathrm{X}$ & $\mathrm{X}$ & Ex \\
\hline Milicia excelsa (Welw.) C. C. Berg & Moraceae & 5 & 2,6 & VU & $\mathrm{X}$ & $\mathrm{X}$ & & In \\
\hline Musanga cecropioides $\mathrm{R}$. Br. Ex Tedlie & Cecropiaceae & 5 & 2,6 & $\mathrm{LC}$ & $X$ & $\mathrm{X}$ & $X$ & In \\
\hline Bombax buonopozense P. Beauv. & Bombacaceae & 2 & 1 & $\mathrm{LC}$ & $\mathrm{X}$ & & $\mathrm{X}$ & In \\
\hline Irvingia gabonensis (Aubry-Leco. ex O'Rorke) Baill. & Irvingiaceae & 2 & 1 & $\mathrm{LC}$ & & $\mathrm{X}$ & $\mathrm{X}$ & Ex \\
\hline Alstonia boonei De Wild & Apocynaceae & 1 & 0,5 & $\mathrm{LC}$ & & $\mathrm{X}$ & & In \\
\hline Carica papaya & Caricaceae & 1 & 0,5 & $\mathrm{NE}$ & $\mathrm{X}$ & & & Ex \\
\hline Mammea africana & Guttiferae & 1 & 0,5 & VU & & $\mathrm{X}$ & & Ex \\
\hline Mansonia altissima & Malvaceae & 1 & 0,5 & NT & & & $\mathrm{X}$ & Ex \\
\hline
\end{tabular}

$\mathrm{LC}=$ minor concern; $\mathrm{VU}=$ Vulnerable; $\mathrm{NT}=$ Threatened in the near future. $\mathrm{YC}=$ young cocoa plantations; $\mathrm{MC}=$ middle cocoa plantation; $\mathrm{OC}=\mathrm{old}$ cocoa plantation. $\mathrm{X}=$ presence; $\mathrm{IN}=$ indigenous species; $\mathrm{EX}=$ Exotic species 
Based on the IUCN (International Union for Conservation of Nature) status of the 21 tree species recorded, $69 \%$ have a Minor Concern (LC), 14\% are Not Evaluated (NE), 19\% are Vulnerable (VU) and 5\% will be threatened in a Near Future (NT). In addition, of the 21 species listed in these CAF, 9 species $(43 \%$ of the trees inventoried) are indigenous compared to $12(57 \%)$ which are exotic. This makes it possible to show the importance of the CAF in the conservation of the native or indigenous biodiversity.

The accumulation curves of the three age classes of CAF showed that whatever the age class of the CAF, the specific wealth continues to grow but weakly. The curve rises from the class of $\mathrm{YC}$ to that of $\mathrm{MC}$ and $\mathrm{OC}$ where it seems to tend towards a plateau. This suggests that even if the species richness does not appear to be total, the sampling approaches to a state of satisfaction (Figure 1).

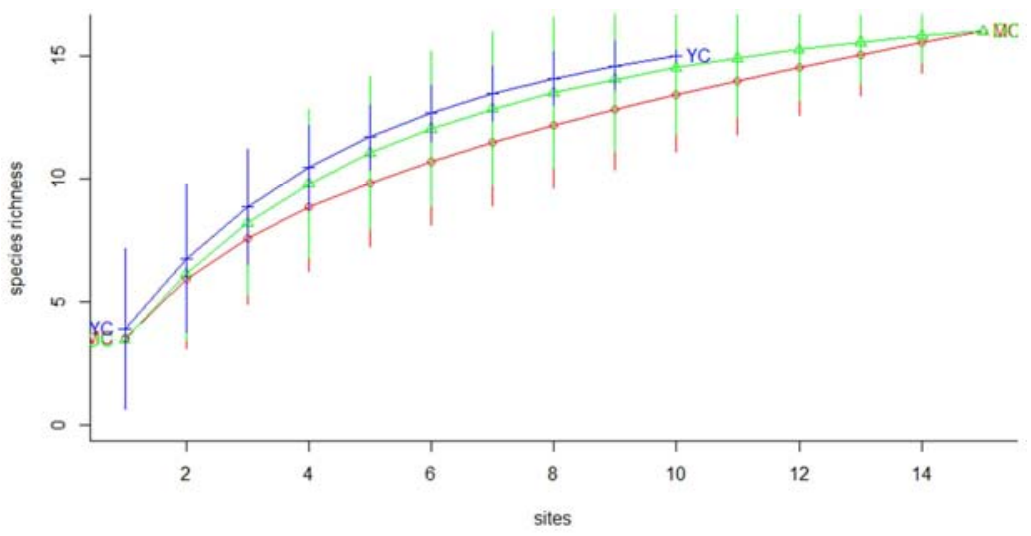

$\mathrm{YC}=$ young cocoa agroforest, $\mathrm{MC}=$ middle cocoa agroforest $\mathrm{OC}=$ old cocoa agroforest

Figure 1. Accumulation curve of the trees species inventoried in SODECAO cocoa agroforestry system.

The non-parametric estimators Chao, Jack1 and Jack2 have showed that the species richness in Talba CAF is high. For these estimators, the precision of the specific wealth estimate varies from $73-81 \%$. In young cocoa (YC) shrubs, it varies from $80 \%$ to $91 \%$; in middle cocoa (MC) it is between $58 \%-71 \%$, while in old cocoa (OC) it is between $85 \%-95 \%$ (Table 2 ).

Table 2. Biodiversity indices and non-parametric estimators of trees species recorded in SODECAO agroforestry system.

\begin{tabular}{|c|c|c|c|c|c|c|c|c|}
\hline Cocoa plantation age class & Plots & Species richness & Shannon & Pielou & Simpson & Jack1 & Jack2 & Chao \\
\hline Young & 10 & 15 & 2.52 & 0.83 & 0.91 & 18.6 & 18.2 & 16.4 \\
\hline Middle & 15 & 16 & 2.35 & 0.66 & 0.88 & 22.5 & 27.0 & 27.4 \\
\hline Old & 15 & 16 & 2.57 & 0.82 & 0.91 & 18.8 & 17.4 & 16.8 \\
\hline SODECAO & 40 & 21 & 2.68 & 0.69 & 0.92 & 25.9 & 28.8 & 27.1 \\
\hline
\end{tabular}

\subsection{Structural Characterization of SODECAO Agroforestry System}

\subsubsection{Diametric Structure}

The diametric structure of the CAF of the studied area had a decreasing exponential form ( $\mathrm{J}$ inverted); a sign of ecological vigor (Figure 2). Classes [10-20 [cm represent
CAF regeneration plants, which are planted by farmers, those of [20-30 [cm, [30-40 [cm, [40-50 [ classes were the future stems to replace those in the process of disappearance especially those of [150-200 [cm class which are represented by the selected large trees and retain as recommended by SODECAO before the establishment of the CAF for their shades and soil fertility sufficiency.

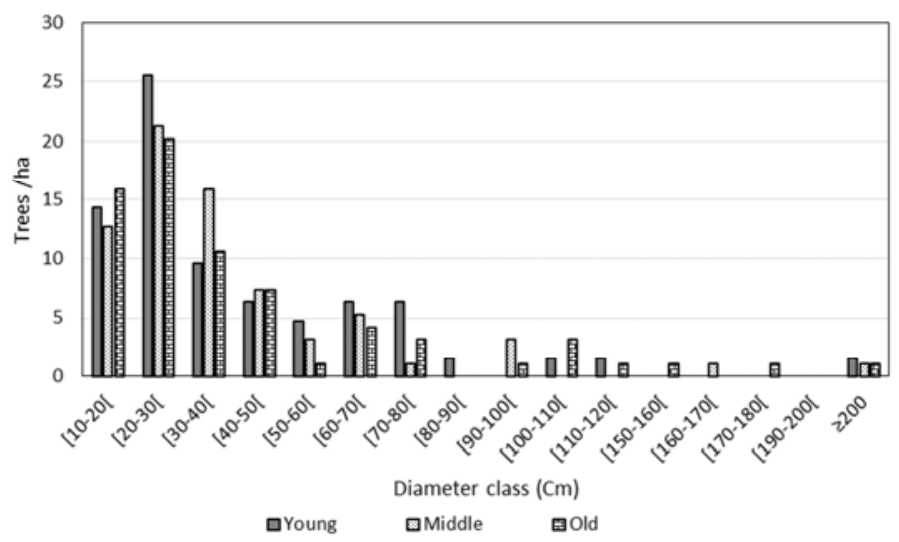

Figure 2. Diametric structure of trees species associated to cocoa shrubs in the SODECAO cocoa agroforest system. 


\subsubsection{Density, Basal Area and Aboveground Biomass}

Cocoa trees stems of SODECAO system are represented by 1104 stems ha ${ }^{-1}$ and associated trees by 77 stems ha $^{-1}$. Depending on the CAF classes, there is a significant difference between the number of cocoa trees per hectare (ANOVA, $p=0.014$ ). The Turkey's test showed that the cocoa trees stems of young CAF are significantly different from the middle CAF. Moreover, the difference between the middle and old CAF was not significant according to the CAF classes (ANOVA, $p=0.91$ ). The mean basal area found was $35.49 \mathrm{~m}^{2} \mathrm{ha}^{-1}$; those of associated trees represented $58 \%$ and those of cocoa trees represented $42 \%$. Cocoa trees, despite their high density ha ${ }^{-1}$, have approximately twice less carbon stock, with a mean value of $29.84 \mathrm{Mg} \mathrm{C}^{-h^{-1}}$ compared to those of associated trees, which stored an average of $70.17 \mathrm{Mg} \mathrm{C} . \mathrm{ha}^{-1}$. The ANOVA test showed that there is significant difference between the total carbon (cocoa + associated trees) stocks of young, middle and old CAF ( $\mathrm{p}=$ 0.021) (Table 3).

Table 3. Density, basal area and carbon stocks in function of cocoa agroforest class.

\begin{tabular}{|c|c|c|c|c|c|c|c|}
\hline $\begin{array}{l}\text { Cocoa plantation } \\
\text { age (years) }\end{array}$ & $\begin{array}{l}\text { Cocoa trees } \\
\text { stems. } \text { ha }^{-1}\end{array}$ & $\begin{array}{l}\text { Trees } \\
\text { associated } \\
\text { stems.ha }^{-1} \\
\end{array}$ & $\begin{array}{l}\text { Basal area of } \\
\text { cocoa trees } \\
\left(\mathrm{m}^{2} \cdot \mathrm{ha}^{-1}\right)\end{array}$ & $\begin{array}{l}\text { Basal area of } \\
\text { trees associated } \\
\left(\mathbf{m}^{2} \cdot \mathbf{h a}^{-1}\right)\end{array}$ & $\begin{array}{l}\text { Carbon stock of } \\
\text { cocoa trees (Mg } \\
\left.\text { C. } \mathrm{ha}^{-1}\right)\end{array}$ & $\begin{array}{l}\text { Carbon stock of } \\
\text { associated trees } \\
\left({\left.\mathrm{Mg} \mathrm{C} . \mathrm{ha}^{-1}\right)}\right.\end{array}$ & $\begin{array}{l}\text { Carbon stocks of } \\
\text { CAF }\left(\mathrm{Mg} \mathrm{C} \mathrm{ha}^{-1}\right)\end{array}$ \\
\hline Young & 1299 & 80 & 14.36 & 23.07 & 26.90 & 73.96 & 100.86 \\
\hline Middle & 950 & 74 & 12.76 & 15.39 & 23.89 & 55.82 & 79.71 \\
\hline Old & 1063 & 77 & 18.49 & 22.41 & 38.72 & 80.73 & 119.45 \\
\hline SODECAO & 1104 & 77 & 15.20 & 20.29 & 29.84 & 70.17 & 100.01 \\
\hline
\end{tabular}

\subsection{Correlation Between the Different Variables in the Cocoa Agroforestry of the Study Area}

The following PCA was obtained from the first 2 axes whose contribution was $\approx 80 \%$. Unlike the abundance of associated trees (per hectare) which is negatively correlated with carbon stocks of CAF, these stocks are positively related to the total basal area of associated trees. However, the abundance/basal area of the cocoa (per hectare) are independent. But, any increase in the number of cocoa shrubs per hectare results in an increase in its basal area. This was contrary to the associated trees where the increase in the number of stems $\mathrm{ha}^{-1}$ was negatively correlated with their basal area (Figure 3).

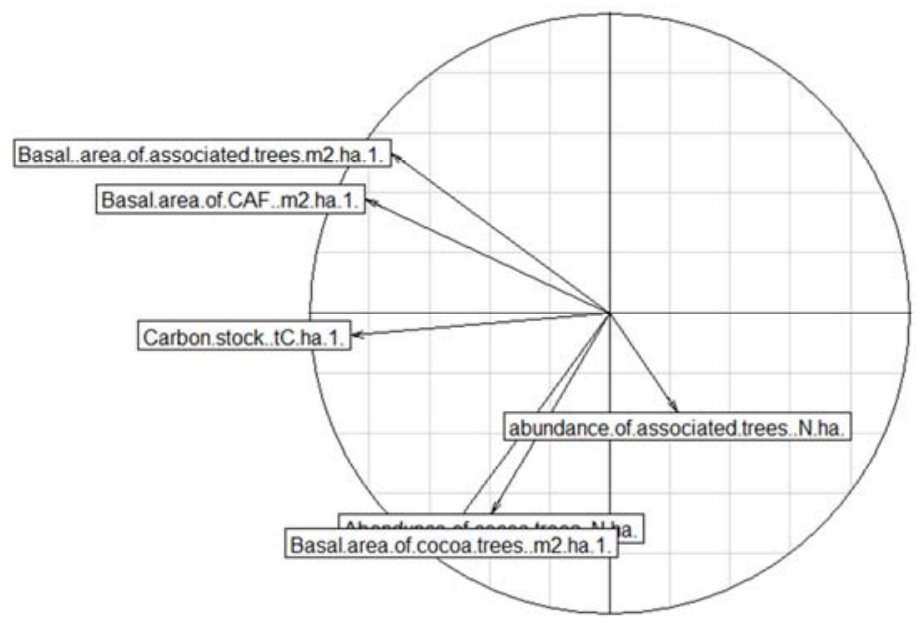

Figure 3. Principal component analysis (PCA) in function of carbon stock, basal area $\left(\mathrm{m}^{2}\right.$ ha $\left.{ }^{-1}\right)$, cocoa number and associated trees of SODECAO agroforest system of Talba locality.

\section{Discussion}

\subsection{Specific Diversity}

A total of 21 species belonging to 19 genera and 14 families were recorded. The results obtained in the typical SODECAO cocoa agroforestry systems identified in Talba locality showed that cocoa farmers retained or introduced some exotic trees species for commercial incomes (timber, non-timber forest products). Moreover, the abundance of some species such as Terminalia superba $(13.1 \%$ of the species inventoried), Ricinodendron heudelotii (11.0\%) and
Dacryodes edulis (10.5\%) were counted amongst the species recommended by SODECAO to cocoa farmers. This also demonstrated their willingness to introduce trees into these plantations because they increase their income and maintain their welfare during the less productive seasons of cocoa. According to SODECAO, a majority of species found in these typical CAF are recommended species for they sufficiency provide shades in CAF systems for good cocoa development and also for the soil fertilization [29]. Exotics species are the most expensive in the locality due to their diversification in services: source of Non-timber forest products (NTFPs), medicinal values, firewood, soil fertility, 
sufficient shades etc. It is for this reason that they are more abundant in these systems compared to native species which, according to the cocoa farmers interviewed, render little services (essentially economic) compared to exotic species and the difficulty to remove them when diameter are important [9-13].

The result of 21 trees species richness found in SODECAO CAF systems are close to the 26 species identified by Manfo [9] in the CAF of the Central Region. However, this diversity is much less than those found by Jagoret [45], Mapongmetsem [46] and Mbolo [47] who recorded 70.61 and 57 species in the CAF of Bokito, Mbankomo and the peri-urban areas of Bafia town respectively. However, the differences observed could be explained by the fact that cocoa farmers in Talba locality set up cocoa agroforests with a maximum implementation of SODECAO recommendations for cocoa cultivation (1111 cocoa shrubs $\mathrm{ha}^{-1}$ and at least 40 associated trees. $\mathrm{ha}^{-1}$ ) whereas in the localities of Bokito, Mbankomo and Bafia, cocoa farmers create complex traditional CAF in which they conserve more tree species due to their difficulty to fell (lack of financial of financial means and good farm tools), their knowledge of tree use, environmental reasons and ignorance/negligence on SODECAO recommendations for cocoa cultivation in Cameroon.

The Simpson index (0.92) and Pielou (0.69) obtained in the CAF clearly showed regularity between the species, with the dominance of some species such as Terminalia superba, Ricinodendron heudelotii and Dacryodes edulis. The Shannon index (2.68) obtained showed that the CAF is a favorable site for the development of these species. These results are similar to those obtained in Nigeria (2.7) [47], Ghana (2.6) [48], and in the Bokito, Zima, and Ngomedzap localities of Cameroon (2.42). However, this value (2.68) is lower than those obtained by Zapfack [27] in the CAF of South Cameroon (3.66). The Pielou index values is higher in young cocoa agroforests (0.83), Middle age cocoa agroforests $(0.66)$ and old cocoa agroforests $(0.82)$ showed a uniformity distribution between species, these results are in agreement with those of Noiha [24] who found the values of 0.75 and 0.78 respectively in young cocoa agroforests and old cocoa agroforests.

Malvaceae, Rutaceae, Guttiferae, Moraceae and Bombacaceae were the most diverse families of trees in CAF of the study area. This could be due to the fact tree species in these families fall in the list of trees associated to cocoa cultivation in the recommendations of SODECOA which encourage farmers to plant or conserve trees that provide soil fertility, sufficient shade for cocoa growth [14-29-49]. Other reasons include: family income diversification by farmers, natural abundance of these tree families in the locality. Indeed, they place special emphasis on other species of exotic nature for their nutritional and medicinal functions (Dacryodes edulis, Persea americana, Citrus sp., Ricinodendron heudelotii) [13]. Thus, among these species with IUCN status conserved, some species are threatened and others are indigenous species. Despite the fact that the conservation potential of tree species has not been evaluated in this study, these results show that typical SODECAO CAF contribute to the conservation of native or threatened trees biodiversity.

\subsection{Structure of SODECAO Cocoa Agroforestry}

The number of trees associated $\mathrm{ha}^{-1}$ is less than the number of cocoa trees $\mathrm{ha}^{-1}$ in $\mathrm{YC}, \mathrm{MC}$ and OC. However, the number of trees associated $\mathrm{ha}^{-1}$ and the number of cocoa trees are higher in YC (1299/80 stem ha $\left.{ }^{-1}\right)$ than in MC (950/74 stem $\left.\mathrm{ha}^{-1}\right)$ and OC $\left(1063 / 77\right.$ stem. ha $\left.^{-1}\right)$. This result is similar to others in Cameroon, which states that cocoa trees densities decreases with the age of agroforest [24-29]. The drop in the density of cocoa shrubs in old cocoa agroforests could be accounted for by the prevalence of cocoa plant diseases, ageing and consequently death of cocoa shrubs. Constant replacement of old, less productive and death cocoa shrubs is therefore required in CAF to maintain a density balance for all ages of CAF. The abundance of small-diameter individuals justifies farmers' tree conservation efforts through planting or by conserving regenerating species in the cocoa plantations [22-27]. This also explains why the number of associated trees $\mathrm{ha}^{-1}(77)$ is higher than the standard recommended by SODECAO (a maximum of 40 trees $\mathrm{ha}^{-1}$ ). The disengagement of SODECAO in 1994 gradually diminished farmers' interest in organizing and managing this type of system [50]. Intensification of cocoa farming is one of the major concerns for farmers to increase their cocoa yields. Thus, an increase in the number of cocoa trees per hectare leads to a considerable decrease in the number of associated trees which directly affects the rate of shade [1449]. These results can also be explained by the fact that Talba locality is found in a forest-savannah transition zone, where the practices of farmers in cocoa farming differ significantly from those adopted by farmers in other production areas of Centre-Cameroon [14].

\subsection{Carbon stock and Correlation Between Different Variables in Cocoa Agroforestry}

A significant reduction of the orchards, which are indeed conducted under a small shade, is a major innovation compared to what is usually practiced by farmers in the CAF of Centre Cameroon. However, although the associated trees are of low-density, the quantities of carbon stocks $(70 \mathrm{Mg}$ $\mathrm{Cha}^{-1}$ ) obtained are still higher than the quantities obtained $\left(30 \mathrm{Mg} \mathrm{C} \mathrm{ha}^{-1}\right)$ for cocoa trees. The carbon stored (100 Mg C ha-1) by SODECAO CAF are similar to the $104 \mathrm{Mg} \mathrm{Cha}^{-1}$ obtained by Asare [48] in CAF of Ghana. This amount is however lower than the $147 \mathrm{Mg} \mathrm{C}$ ha-1 obtained in the complex CAF of South Cameroon for the simple reason that these systems are most often very abundant in terms of trees species abundance [27]. However, the fact that the quantities of stored carbon $\left(100 \mathrm{Mg} \mathrm{C} \mathrm{ha}^{-1}\right)$ are close to the $129 \mathrm{Mg} \mathrm{C}$ $\mathrm{ha}^{-1}$ found by Tsoumou [18] in Congo forests shows the level of involvement of CAF in the mitigation of the effects of climate change compared to the carbon sequestration potential of natural ecosystems [42].

The PCA shows that carbon stock is positively correlated 
with the basal area of associated trees in contrast to the abundance of these trees abundance. Indeed, most of the trees of small diameter are more abundant in these CAF or the increasing of tree diameter is correlated positively to the quantity of carbon stock. Moreover, in this system, the farmers often resort to a selective replacement of the senescent or less productive cocoa plants by seedlings in order to ensure the perennially of the cocoa trees, which would not only be translated by an increase in the number of cocoa trees per hectare and consequently a decrease in the number of shade trees [49]. Thus, the strong correlation between the abundance of cocoa shrubs and their basal area results in the fact that, cocoa shrubs maintain an almost constant diameter after attaining the adult age [19].

\section{Conclusion}

This study carried out in typical SODECAO agroforestry systems of the locality of Talba made it possible to identify 21 species belonging to 19 genera and 14 families. The values of the diversity indices obtained confirmed that typical SODECAO agroforests are favorable for trees biodiversity conservation, even if they are low. Thus, the implementation of this typical SODECAO CAF system is favorable for the protection and conservation of some trees species which are indigenous or introduced in CAF ecosystems. In the case of this study, $19 \%$ of trees species found are vulnerable and $5 \%$ will be threatened in the near future. Indeed, $43 \%$ of the inventoried species are indigenous compared to $57 \%$ which are exotic. Important amounts of carbon are stored in trees associated to cocoa shrubs in cocoa agroforests even though the diameters of these trees are not large in the locality. Moreover, the summation of carbon stored by cocoa shrubs and associated trees in cocoa agroforests is important for the mitigation of climate change effects. However, despite the fact that CAF are a major factor of forest degradation in this study area, they are one of the major solutions for climate change mitigation, because they reconcile ecological interests with the existential concerns of farmers. Moreover, given that Cameroon is still in the implementation phase of REDD +, this study is important in the sense that it has shown that CAF could be considered like an alternative solution for biodiversity conservation and climate change mitigation since the quantities of carbon stored are reasonable $\left(100 \mathrm{Mg} \mathrm{C} \mathrm{ha}^{-1}\right)$.

\section{References}

[1] Dounias, E. 1995. Composer autour d'une composée Chromolaena odorata et systèmes agraires des forêts tropicales humides. Atelier international African farmers and their environment in a long term perspective, Wageningen. $111 \mathrm{p}$.

[2] Ruf, F. 1995. Booms et crises du cacao. Les vertiges de l'or brun. Karthala Paris, (France).

[3] Ngono, F., Mala, A. W., Levang, P. and Ambang, Z. 2015. Evolution des systèmes agroforestiers cacao et impact environnemental à Mbangassina: cas du village Talba. Revue
Scientifique et Technique Forêt et Environnement du Bassin du Congo. Vol. 5.62-67.

[4] Mbolo, A. M., Zekeng, J. C., Mala, A. W., Fobane, J. L., Chimi, D. C., Nyako, M. C., Tamandjong, V. 2016. The role of Cocoa agroforestry in conserving forest tree diversity in Central Region of Cameroon. Agrofor. Sys. 90 (4), 577-590.

[5] Deheuvels, O. 2011. Compromis entre productivité et biodiversité sur un gradient d'intensité de gestion de systèmes agroforestiers à base de cacaoyers de Talamanca, Costa Rica. Thèse de Doctorat: SupAgro de Montpellier, Montpellier (France). $185 \mathrm{p}$.

[6] Nair, P. K. R. 2012. Carbon sequestration studies in agroforestry systems: a reality-check. Agrofor. Sys. Vol. 86. 243-253 doi: 10.1007/s10457-011-9434-z.

[7] Losch, B., Fusillier, J. L., Dupraz, P. O. and Ndjoya, J. 1991. Stratégies des producteurs en zone caféière et cacaoyère du Cameroun: Quelles adaptations à la crise ? Cameroun: Collection DSA 12, DSA-CIRAD. 252 p.

[8] Jagoret, P. and Nyassé, S. 2003. Intensification raisonnée du verger de cacaoyer Camerounais par l'identification des systèmes de productions compétitifs et durables. Rapport annuel scientifique et technique IRAD/CIRAD, projet Mise au point de systèmes de cacaoculture compétitif et durable en Afrique FSP. 2000- 137p.

[9] Manfo, D. A., Tchindjang, M. and Youta, H. J. 2015. Systèmes agroforestiers et conservation de la biodiversité dans un milieu fortement anthropisé: le cas d'Obala Revue Scientifique et Technique Forêt et Environnement du Bassin du Congo. Vol. 5.

[10] David, O., Oke and Gailyson, Y. J. 2013. Traditional agroforestry practices and woody species conservation in the derived savanna ecosystem of Adamawa state, Nigeria Biodiver. J. Vol. 4. $\mathrm{N}^{\circ} 3$.

[11] Zapfack, L., Engwald, S., Sonké, B., Achoundong, G., Mandong, B. A. 2002. The impact of land use conversion on plant biodiversity in the forest zone of Cameroon. Biodiversity and Conservation. Vol. 11. $\mathrm{N}^{\circ} 11$.

[12] Harvey, C. A, Gonzales, J. G and Somarriba, E. 2006. Dung beetle and terrestrial mammal diversity in forest, indigenous agroforestry systems and plantain monocultures in Talamanca, Costa Rica. Biodiversity and Conservation. Vol. 15.

[13] Sonwa, D., Nkongmeneck, B. A., Weise, S. F., Tchatat, M., Adesina, A. A., and Janssens, J. J. M. 2007. Diversity of plants in cocoa agroforêts in the humid forest zone of Southern Cameroon. Biodiversity and Conservation. Vol. 16.

[14] Tonka, M., Jagoret, P., Tchouamo, I. R. and Couve C. 2008. Caractérisation des systèmes de cacaoculture agro-forestiers dans la zone de front pionnier du Centre Cameroun. Atelier de réflexion «Les agroforêts d'Afrique de l'Ouest et du Centre: dynamiques, performances et avenir?» Sérédou (Guinée). 8 p.

[15] Gockowski, J. and Sonwa, D. 2011. Cocoa intensification scenarios and their predicted impact on $\mathrm{CO} 2$ emissions, biodiversity conservation, and rural livelihoods in the Guinea rain forest of West Africa. Envir. Manage. Vol. 48.

[16] Somarriba, E., Cerda, R., Orozco, L., Cifuences, M., Davila, H., Espin, T., Mavisoy, H., Avila, G., Alvarado, E., Poveda, V., Astorga, C., Say, E. and Deheuvels, O., 2013. Carbon stocks and cocoa yields in agroforestry systems of Central America. Agricul. Ecosys. Env. Vol. 173. 
[17] Zapfack, L., Noiha, N. V., Dziedjou, K. P. J., Zemagho, L., Fomete, N. T. 2013. Deforestation and carbon stocks in the surroundings of Lobéké National Parc (Cameroon) in Congo Basin. Environment and Natural Resources Research. Vol. 3. $\mathrm{N}^{\circ} 2$.

[18] Tsoumou, B. R., Lumandé, K. J., Kampé, J. P. and Nzila, J. D. 2016. Estimation de la quantité de Carbone séquestrée par la Forêt Modèle de Dimonika (Sud-ouest de la République du Congo). Revue Scientifique et Technique Forêt et Environnement du Bassin du Congo. Vol. 6.

[19] Zapfack, L., Chimi, D. C., Noiha, N. V., Zekeng, J. C., Meyan-ya, D. G. R. and Tabue, M. R. B. 2016. Correlation between Associated Trees, Cocoa Trees and Carbon Stocks Potential in Cocoa Agroforests of Southern Cameroon. Sustainability in Environment. Vol. 1. № 2 .

[20] Dixon, J., Gulliver, A. and Gibbon, D. 2001. Farming systems and poverty. Improving farmers livehoods in a changing world. FAO, Rome.

[21] FAO, 2009. Directives pour la Planification de l'Utilisation des Terres. Département du développement durable, archives de document de la FAO, 87-89.

[22] Sonwa, D. J., Weise, S. F. and Janssens, M. J. J. 2002. Etude de cas d'aménagement forestier exemplaire en Afrique centrale: Les systèmes agroforestiers cacaoyers Cameroun. Cameroun: FAO, Départements des forêts.

[23] Bhagwat, S. A., Willis, K. J., Birks, H. J. B. and Whittaker, R. J. 2008. Agroforestry: A refuge for tropical biodiversity? Trends in Ecology and Evolution. Vol. 23. N5.

[24] Noiha, N. V., Zapfack, L. and Mbade, L. F. 2015. Biodiversity Management and Plant Dynamic in a Cocoa Agroforest (Cameroon). International Journal of Plant \& Soil Science. Vol. 6. $\mathrm{N}^{\circ} 2$.

[25] Champaud, J. 1966. L'économie cacaoyère du Cameroun. Cah. Orstom, ser. Sci. hum. Vol.3. №3.

[26] Santoir, C. 1995. Les équipements collectifs. In C. Santoir \& A. Bopda, eds. Atlas régional Sud-Cameroun. ORSTOM \& MINREST- (Cameroun). 37-39.

[27] Mbog, P. D. 1996. Contribution de l'Union européenne à la restructuration de la filière cacao au Cameroun. Conférence de l'ECOPM, sur l'avenir des relations UE-ACP au-delà de Lomé IV, 12-14 juin 1996. Maastrich.

[28] Varlet, F. 1997. Réforme des institutions dans les filières cafécacao au Cameroun. Chronique des années 1990 à 1997. CIRAD-SAR, Document No11, Montpellier, France.

[29] Mbondji, P. 2010. Le cacaoyer au Cameroun. Yaoundé: Presse de l'université catholique d'Afrique Centrale. 254 p.

[30] Ndoumbè, M. 2003. Impact of removing disease pods on cocoa black pod caused by Phythopththora megakarya and on cocoa production in Cameroon. Crop Protection. Vol. 23.

[31] Letouzey, R. 1985. Notice de la carte phytogéographique du Cameroun au 1: 500.000 . 5 documents et 6 cartes. Toulouse: Institut de la Carte Internationale de la Végétation.

[32] Ambassa-Kiki, R. and Mvondo-Zé, D. 2001. Les différentes terres agricoles du Cameroun. Yaoundé, Saild. In: La voix du
Paysan, recueil de fiches techniques pour l'entrepreneur rural, tome 2. Pp. 9-20.

[33] Adou, Y. C. Y., Blom, E. C., Denguéadhé, K. T. S., Rompaey, V. R. S. R., N'Guessan, K. E., Wittebolle, G. and Bongers, F. 2010. Diversité floristique et végétation dans le Sud du Parc National de Tai: Tropenbos.

[34] Chao, A. 1984. Non-parametric estimation of the number of classes in a population. Scand. J. Statist. Vol. 11.

[35] Burnham, K. P. and Overton, W. S. 1979. Estimation robuste de la taille de la population lorsque les probabilités de capture varient selon les animaux. Ecology. Vol.60.

[36] UICN, 2001. Catégories et Critères de l'UICN pour la Liste Rouge. Version 3.1. Commission de la sauvegarde des espèces de l'UICN. UICN, Gland, Suisse et Cambridge, RoyaumeUni. 37 p.

[37] Zanne, A. E., Lopez-Gonzalez, G., Coomes, D. A., Ilic, J., Jansen, S., Lewis, S. L., Miller, R. B., Swenson, N. G., Wiemann, M. C. and Chave, J. 2009. Global wood density database. Retrieved from http://www.hdl.handle.net/10255/dryad.235 2009. Global wood density database. Retrieved from http://www.hdl.handle.net/10255/dryad.235

[38] Chave, J., Rejou-Mechainn, M., Burquez, A., Chidumayo, E., Colgan, S. M., Delitti, B. C. W., Vieilledent, G. 2014. Improved allometric models to estimate the aboveground biomass of tropical trees. Glob. Change Biol., http://dx.doi.org/10.1111/gcb.12629.

[39] Chave, J., Andalo, C., Brown, S., Cairns, M. A., Chambers, J. Q., Eamus, D., Fölster, H., Fromard, F., Higuchi, N., Kira, T., Lescure, J. P., Nelson, B. W., Ogawa, H., Puig, H., Riera, B. and Yamakura, T. 2005. Tree allometry and improved estimation of carbon stocks and balance in tropical forests. Oecologia. Vol.45.

[40] Djuikouo, K. M. N., Doucet, J. L., Nguembou, K. C., Simon, L., Lewis, L. S. and Sonke, B. 2010. Diversity and aboveground biomass in three tropical forest types in the Dja Biosphere Reserve, Cameroon. Afr. J. Ecol. Vol. 48.

[41] Lewis, S., Sonke, B., Sunderland, T., Begne, S. K., Gonzale, L. G., Van der Heijden, M. F. G., Phillips, L. O., AffumBaffoe, K., Timothy, R., Baker, R. T., Banin, L., Bastin, J. F., Beeckman, H., Boeckx, P., Bogaert, J., De Cannier, C., Chezeaux, E., Clark, J. C., Collins, M., Djagbletey, G., Djuikouo, K. M. N., Droissart, V., Doucet J. L., Ewango, N. E. C., Fauset, S., Feldpausch, R. T., Foli, G. E., Gillet, J. F., Hamilton, C. A., Harris, J. D., Hart, B. T., De Haulleville, T., Hladik, A., Hufkens, K., Huygens, D., Jeanmart, P., Jeffery, J. K., Kearsley, E., Leal, E. M., Lloyd, J., Lovett, C. J., Makana, J. R, Malhi, Y., Marshall, R. A., Lucas Ojo, Peh, S. H. E., Pickavance, G., Poulsen, R. J., Reitsma, M. J., Sheil, D., Simo, M., Steppe, K., Taedoumg, E. H., Talbot, J., Taplin, R. D. J., Taylor, D., Thomas, C. S., Toirambe, B., Verbeeck, H., Vleminckx, J., White, T. J. L., Willcock, S., Woell, H. and Zemagho, L. 2013. Aboveground biomass and structure of 260 African tropical forests. Phil. Trans. R. Soc. B. 368, http://dx.doi.org/10.1098/rstb.2012.0295.

[42] Hairiah, K., Ekadinata, A., Sari, R. R. and Rahayu, S. 2011. Petunjuk praks Pengukuran cadangan karbon dari ngkat plot ke ngkat ben-tang lahan. World Agroforestry Centre, ICRAF South- East Asia and University of Brawijaya (UB), Malang, Indonesia: ISBN 978-979-3198-53-8. 
[43] Cummings, D., Boone, K. J., Perry, D. and Hughes, R., 2002. Aboveground Biomass and Structure of Rainforests in the Southwestern Brazilian Amazon. For. Ecol. Manage. Vol.163.

[44] Brown S. et Pearson T., 2005. Guide de mesure et de suivi de $C$ dans les forêts et prairies Herbeuses. Rome: Rapport présenté à l'agence Américaine pour le développement international. Forestry Paper. 39p

[45] Jagoret, P., Kwesseu, J., Messie, C., Michel-Dounias, I. and Male, 'Z. E. 2014. Farmers' assessment of the use value of agrobiodiversity in complex cocoa agroforestry systems in central Cameroon. Agrofor. Syst., http://dx.doi.org/10.1007/s10457-014-9698-1

[46] Mapongmetsem, P. M., Etchiké, D. and Ngassoum, M. B. 2016. Conservation et valorisation de la biodiversité dans les agroforêts de la zone périurbaine de la ville Bafia (Région du Centre au Cameroun). Revue Scientifique et Technique Forêt et Environnement du Bassin du Congo. Vol. 6.
[47] Oke, D. O. and Odebiyi, K. A. 2007. Traditional cocoa-based agroforestry and forest species conservation in Ondo State, Nigeria. Agric. Ecosyst. Environ. Vol. 122.

[48] Asare, A. and Tetteh, D. A. 2010. The role of complex agroforestry systems in the conservation of forest tree diversity and structure in southeastern Ghana. Agrofor. Syst. Vol.79.

[49] Bisseleua D. H. B. \& Stefan V., 2008. Plant biodiversity and vegetation structure in traditional cocoa forest gardens in southern Cameroon under different management. Biodiversity and Conservation. Vol. 17.

[50] Annon, 2000. Etudes socio-économiques régionales au Cameroun. Province du Centre. Ministère de la Planification et l'Administration du Territoire, Projet PNUD-OPS CMR/98/005/01/99. Yaoundé, 52 p. 